Original Research Paper

\title{
Thermodynamic Model of Calcium Carbonate System of Soil Solution
}

\author{
${ }^{1}$ Abdulmalik A. Batukaev, ${ }^{2}$ Anatoliy P. Endovitsky, ${ }^{2}$ Andrey G. Andreev, \\ ${ }^{3}$ Tatiana M. Minkina, ${ }^{2}$ Valeriy P. Kalinichenko, ${ }^{3}$ Marina V. Burachevskaya, \\ ${ }^{2}$ Zaurbek S. Dikaev, ${ }^{3}$ Saglara S. Mandzhieva and ${ }^{3}$ Svetlana N. Sushkova ${ }^{3}$ \\ ${ }^{I}$ Chechen State University, Grozny, Russia \\ ${ }^{2}$ Institute of Fertility of Soils of South Russia, Rostov Region, Russia \\ ${ }^{3}$ Southern Federal University, Rostov-on-Don, Russia
}

Article history

Received: 06-01-2016

Revised: 28-02-2016

Accepted: 16-05-2016

Corresponding Author: Tatiana M. Minkina,

Southern Federal University,

Rostov-on-Don, Russia

Tel: +7(918)5531632

Email: tminkina@mail.ru

\begin{abstract}
Carbonate system determines the basic processes of soil formation and evolution. The aim of research was to show the importance of chemical Carbonate Calcium Equilibrium (CCE) in soil solutions. CCE causes a degree of soil solution's saturation with $\mathrm{CaCO}_{3}$ as a factor of carbonate geochemical cycle. CCE depends on chemical composition, $\mathrm{pH}$, Eh, buffering properties of liquid phase, dissolution, migration, precipitation of carbonates in the soil profile and landscape, ion exchange processes at the interface of soil solid and liquid phases. At high ionic force in soil solution are formed electrically neutral ion pairs $\mathrm{CaCO}_{3}{ }^{0} ; \mathrm{CaSO}_{4}{ }^{0}$, $\mathrm{MgCO}_{3}{ }^{0}, \mathrm{MgSO}_{4}{ }^{0}$ and charged ion pairs $\mathrm{CaHCO}_{3}{ }^{+}, \mathrm{MgHCO}_{3}{ }^{+}, \mathrm{NaCO}_{3}{ }^{-}$, $\mathrm{NaSO}_{4}^{-}, \mathrm{CaOH}^{+}, \mathrm{MgOH}^{+}$. The object of research-saline soil of dry steppe zone of Southern Russia. This soil is moderately thick, solonized, humus $2.6 \%$, physical clay $47.7 \%$, clay $29.5 \%, \mathrm{CaCO}_{3} 0.15 \%$ (up to $3-10 \%$ at the depth of $0,8-1,5 \mathrm{~m}), \mathrm{pH}=7.8-9.0$, readily soluble salts in soil solution from $0.2 \%$ in $0-5 \mathrm{~cm}$ to $3.5 \%$ in $70-80 \mathrm{~cm}$, exchangeable cations: $\mathrm{Ca}^{2+}-182$ mmol kg ${ }^{-1}, \mathrm{Mg}^{2+}-65 \mathrm{mmol} \mathrm{kg}{ }^{-1}, \mathrm{Na}^{+}-34 \mathrm{mmol} \mathrm{kg}{ }^{-1}$. The soil solution was extracted from soil layers at the depth of 0-150 cm. Ion's composition of the soil solution was determined using standard analytical methods. The mathematical model shows the real state of associated ions at high ionic strength of saline soil solution. On the basis of algorithm CCE a computer program was developed The concentration of free and associated ion form is a result of iteration beginning from analytical ion concentration considering ion material balance, linear interpolation of equilibrium constants, method of ionic pairs, laws of: Initial concentration preservation, operating masses of equilibrium system. Concentration constants of ion pair dissociation were calculated following the law of operating masses. Were determined a quantity of ion free form and the coefficient of ion association $\gamma_{\mathrm{e}}$ as a ratio of ion's free form to its analytical content $\gamma_{\mathrm{e}}=\mathrm{C}_{\mathrm{ass}} / \mathrm{C}_{\mathrm{an}}$. Because of association of ions, which differs in soil layers: The chemical equilibrium in soil solution determines high mobility of carbonates, transformation of solution, carbon sink from soil.
\end{abstract}

Keywords: Ion's Association, Soil Solution

\section{Introduction}

The process of formation of the chemical composition of soil solution is very complex. It is influenced by various factors. One such factor is a nature of most important chemical equilibrium in soil solutions-Carbonate Calcium Equilibrium (CCE).
CCE depends on the state of chemical composition, $\mathrm{pH}$, Eh, buffering properties of liquid phase, dissolution, migration, precipitation of carbonates in the soil profile and landscape, ion exchange processes at the interface of solid and liquid phases. The study of $\mathrm{CCE}$ is a base for $\mathrm{CaCO}_{3}$ solubility calculation at given conditions. 
The uncertainties where found of physical and biogeochemical models of aquatic and terrestrial systems, improvement of models are recomended (Romanou et al., 2013).

Concerning the carbon sequestration and climate engineering the soil as a drain for carbon sink is to be assessed. Uncertainty of Biosphere is linked to geochemical cycle of soil (Bahn et al., 2015; Seneviratne et al., 2012; Reichstein et al., 2013). The heterogeneity of carbon stream is a function of landscape (Ågren et al., 2014). In boreal landscape it is a major source of dissolved organic carbon. In the semiarid and arid catchments the soil solution equilibrium causes the carbon mobility into the soil, thus the possibility of uncontrolled carbon flux from soil and biosphere is high.

The sinking of carbon is one of the key components of the carbon cycle and global climate system (Lima et al., 2013). It is important to quantify the carbon source/sink nature, determine its drivers (Turi et al., 2014). Water saturation with $\mathrm{CaCO}_{3}$ gives an adverse biogeochemical effect (Evans et al., 2014).

Soil solution equilibrium helps to represent properly the link of soil and vegetation (Melton and Arora, 2014). The CCE of water and soil solution influences the growth of leading agents of biosphere - water and soil organisms (Teichert and Freiwald, 2014). Soil solution varies on temporal and spatial scales (Mezbahuddin et al., 2014). Anthropogenic influence on soil is dangerous (Leiber-Sauheitl et al., 2014). The problem of carbon cycle is linked to release of entrapped methane form the soil structure, especially when soil is in a state of disturbance (Nauer et al., 2013). The sinks and sources of carbon are the key point for terrestrial and aquatic ecosystem models, drivers of atmospheric $\mathrm{CO}_{2}$ concentration, biosphere functioning and climate (Peng et al., 2014).

CCE provides understanding of key biogeochemical element cycles (Müller et al., 2014), ecosystem state and management (Endovitsky et al., 2015a; Starcev Viktor and Kalinichenko, 2015).

The soil is an important part of terrestrial system. CCE of the soil solution is important for understanding the origin of Pedosphere variability of soil solution, destruction and synthesis of organics, secondary minerals and compounds (Amakor et al., 2013; Hunenberger and Relf, 2011; Visconti and de Paz, 2012).

The mineralization of soil solution varies because of geological and biological composition of the local biogeosystem, regional and local water-mass-transfer, wetting and drying circles of the soil, biological process in the soil. CCE is a base for modeling the heavy metals transfer in soil (Anisimov et al., 2015; Endovitskii et al., 2014; Endovitsky et al., 2014a; 2014b; 2015b; Chaplygin et al., 2014).

The regularities of water solution are caused by chemical equilibrium (Debye and Hückel, 1923;
Bjerrum et al., 1958; Davies, 1962; Garrels and Christ, 1965; Butler, 1998; Lewis and Randell, 2015; Adams, 1971; Sposito, 1984; Orlov, 1992), including the low mineralized waters (Levchenko, 1921). Ion's association explains the oversaturation natural water with carbonates, as well as migration and accumulation of carbonates (Minkin et al., 1977). The carbonate system of water solution is influenced by biological process, soil-atmosphere gas exchange, partial pressure and seasonal cycle of $\mathrm{CO}_{2}$.

Under natural conditions not content of $\mathrm{HCO}_{3}{ }^{-}, \mathrm{CO}_{3}{ }^{2-}$ and $\mathrm{H}_{2} \mathrm{CO}_{3}$ in soil solution depends on $\mathrm{pH}$, but namely the ratio of forms of $\mathrm{CCE}$ determines the $\mathrm{pH}$ value, buffering and redox properties of the soil solution, nature of ion exchange in the system "solid phase-solution", solubility of many mineral and organic compounds.

The precipitation or dissolution of $\mathrm{CaCO}_{3}$ is linked to removal or receipt of $\mathrm{Ca}^{2+}, \mathrm{HCO}_{3}^{-}$and $\mathrm{CO}_{3}{ }^{2}$ according to CCE.

An important characteristic of $\mathrm{CCE}$ is a degree of saturation of the soil solutions with $\mathrm{CaCO}_{3}$. However, it does not give a clear answer to the question about the formation of $\mathrm{CaCO}_{3}$. The studies of carbonate equilibrium in surface waters show that the state of saturation or super saturation of natural waters with $\mathrm{CaCO}_{3}$ demonstrates only the possibility of a precipitate forming, but not always the $\mathrm{CaCO}_{3}$ precipitates from supersaturated solutions. The link between solution's saturation with $\mathrm{CaCO}_{3}$ and its precipitation depends on physicochemical and biochemical processes, which stably hold $\mathrm{CaCO}_{3}$ precipitation.

The existence of solutions supersaturated with $\mathrm{CaCO}_{3}$ is a property of the CCE. Conditions and sustainability of solution's super-saturation with $\mathrm{CaCO}_{3}$ varies. One cause is related to the properties of solutions of calcium hydro-carbonate. It is the formation of a solid phase which differs in chemical composition from the solution. The second-at extremely low concentration of $\mathrm{CO}_{3}{ }^{2-}$ ions in solution the spatial orientation is required for onset of crystallization, which is probably hampered by the huge number of surrounding ions $\mathrm{HCO}_{3}{ }^{-}$. Another reason which determines the high degree of calculated saturation of soil solution with $\mathrm{CaCO}_{3}$ is the complexation of $\mathrm{Ca}^{2+}$ with organic matter.

According to emergence of electrically neutral $\mathrm{CaCO}_{3}{ }^{0} ; \mathrm{CaSO}_{4}{ }^{0}, \mathrm{MgCO}_{3}{ }^{0}, \mathrm{MgSO}_{4}{ }^{0}$ and charged ion pairs $\mathrm{CaHCO}_{3}{ }^{+}, \mathrm{MgHCO}_{3}{ }^{+}, \mathrm{NaCO}_{3}{ }^{-}, \mathrm{NaSO}_{4}{ }^{-}, \mathrm{CaOH}^{+}$, $\mathrm{MgOH}^{+}$, the regularities of soil solution are much more diverse comparing to water systems (Orlov, 1992; Levchenko, 1921; Hunenberger and Relf, 2011; Stoyanov et al., 2011; Raiteri et al., 2012; Zhang et al., 2012; Tertre et al., 2011).

The soil solution extraction sampling destructs its bonds to disperse system. That is why the mathematical model of soil solution in discrete parts of soil continuum 
at different soil moisture and ionic strength is more reliable than solution direct extraction. At high ionic strength of soil solution the lows of quasicrystalline water structure, supercritical water, nonthermodynamic techniques of associated ion pairs modeling in nanotubes and supercritical water, direct ion pair study, other methodological approaches (Johnston et al., 2010; Plugatyr et al., 2011; Chialvo et al., 1995; Saito, 2013; Raiteri et al., 2012; Maiti and Rogers, 2011; Lui et al., 2011; Farnum et al., 2011; Kielpinski, 2013, Westerlund et al., 2011; Besser-Rogac et al., 2011; Wang et al., 2014; Izgorodina et al., 2014; Luo et al., 2013; (Zhang et al., 2012; Tertre et al., 2011; Wiatrak, 2014; Jiang, et al., 2012) describe the system properly.

For the most cases of soil solution are suitable the basic laws of ion association solution thermodynamics and thermodynamic models of macro-processes of saturation in soil solution, transfer, metamofization and accumulation of salts in the three-dimensional soil continuum (Minkina et al., 2012a).

The aim of the research is to show the role of CCE in soil solution on the basis of thermodynamics mathematical model of CCE of soil solution.

\section{Materials and Methods}

\section{Study Area}

The South-East of the Russian Federation, Rostov region. Lower Don.

Object of research-the dry steppe chestnut saline solonetzic soil of Southern Russia. The climate is arid, annual precipitation of $300-350 \mathrm{~mm}$. The parent rocks are Carbonate and Carbonate-sulfate loess-like loam and clay.

The solonetz soil is moderately thick, medium solonized, humus $2.6 \%$, physical clay $47.7 \%$, clay $29.5 \%, \mathrm{CaCO}_{3} 0.15 \%$ (up to $3-10 \%$ at the depth of $0,8-$ $1,5 \mathrm{~m}), \mathrm{pH}=7.8$, exchangeable cations: $\mathrm{Ca}^{2+}-182 \mathrm{mmol}$ $\mathrm{kg}^{-1}, \mathrm{Mg}^{2+}-65 \mathrm{mmol} \mathrm{kg}{ }^{-1}, \mathrm{Na}^{+}-34 \mathrm{mmol} \mathrm{kg}{ }^{-1}$.

\section{Sampling and Analysis}

The soil section has been made in semihydromorphic landscape. Soil species were sampled from a section wall down to the depth of $1 \mathrm{~m}$, samples from the deeper soil layers were made by the soil auger, drill cup diameter $5 \mathrm{~cm}$.

In procedure of soil samples preparation the soil was crushed and sifted, openings $2 \mathrm{~mm}$, than mixed with quartz sand in ratio 1:2 (Carter and Gregorich, 2007; Minkina et al., 2012b), than soil from every soil layer was charged into glass tube, inner diameter of $3.4 \mathrm{~cm}$, length of $100 \mathrm{~cm}$. At the bottom of the tube was mounted a solution draining off outlet. Soil solution was allocated directly with ethyl alcohol poured on the top of soil column. The volume of soil solution emitted from every soil column was 20-60 mL.
Soil solution was analyzed by standard methods (Carter and Gregorich, 2007; Visconti and de Paz, 2012).

Moisture of soil was determined by thermostat $105^{\circ} \mathrm{C}$ method. Dry residual of soil was determined by thermostat $105^{\circ} \mathrm{C}$ method. $\mathrm{pH}$ was measured in thermostat $\left(20 \pm 0,2^{\circ} \mathrm{C}\right)$ by $\mathrm{pH}$-meter with a glass electrode. The carbonate and bicarbonate anions were titrated directly by $0.01 \mathrm{M}$ hydrochloric acid detenting titration, endpoint on color change of indicators-phenolphthalein and methyl orange. The chloride ion was detected by argentometric method with potassium chromate. The total content of $\mathrm{Ca}^{2+}$ and $\mathrm{Mg}^{2+}$ was measured by complexometric titration. In another aliquot $\mathrm{Ca}^{2+}$ was measured in complexometric. $\mathrm{Mg}^{2+}$ was calculated as a difference. The sulfate was analyzed by $\mathrm{BaSO}_{4}$ sedimentation method. $\mathrm{Na}^{+}$by flame photometric detection.

The experiment was performed in triplicate.

All statistical calculations were performed using Microsoft Excel 2010.

\section{Results}

Carbonate system is complex and important chemical system of soil solution because it influences the nature of many basic processes of formation and evolution of a certain type of soil. Carbonate system includes a number of dynamic equilibriums (Fig. 1).

The CCE of soil solution is an adsorption-hydration balance between solution, gas phase, bioorganic phase. This balance includes step dissociation of carbonic acid; CCE between solution, soil absorbing complex, sediments of $\mathrm{CaCO}_{3}$ and solid phase, the ion equilibrium of water. An important characteristic of the $\mathrm{CCE}$ is a degree of saturation of solution with $\mathrm{CaCO}_{3}$. The deposition or dissolution of $\mathrm{CaCO}_{3}$ caused by receipt or removal of $\mathrm{Ca}^{2+}, \mathrm{HCO}_{3}{ }^{-}$and $\mathrm{CO}_{3}{ }^{2-}$ from solution, as well as carbonate equilibrium shift, change the ionic composition of the soil solution. Thus the type of migration and accumulation of carbonates in soil profile becomes special.

The analytical composition of typical dry steppe chestnut saline solonetzic soil of Southern Russia is given in Table 1.

It was shown here above that analytical composition of solution is suitable characteristic at low of main ions concentration only. The measure of real chemical reactions is ions activity.

Was determined the real state of the main ions in soil solutions on the basis of ionic strength and ion's association in soil solution. The model of soil solution equilibrium was proposed (Endovitskii and Minkin, 1979; Minkin and Endovitsky, 1986; Endovitskii et al., 1985; 2009).

The algorithm and computer programs were developed. 


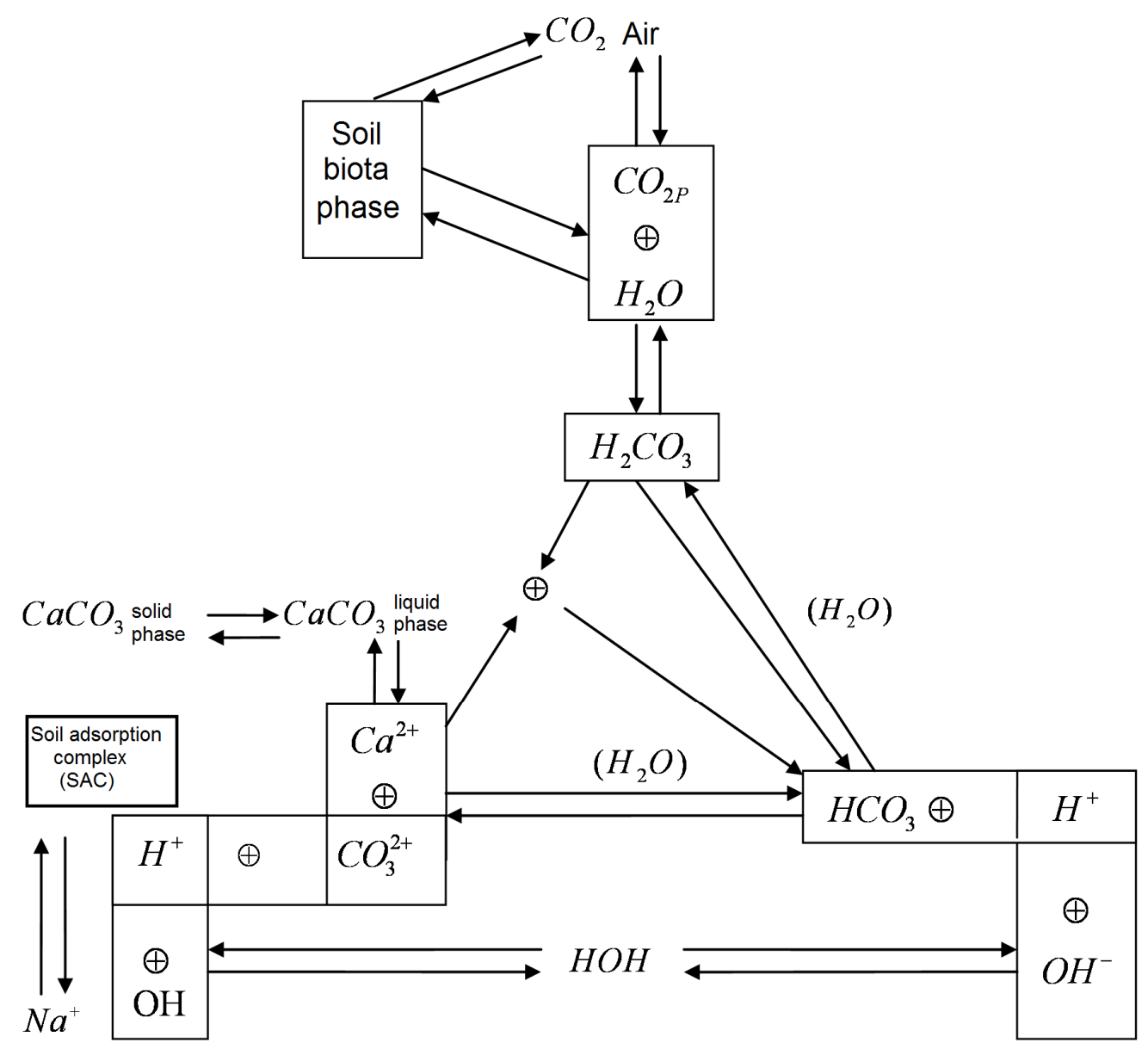

Fig. 1. The scheme of calcium-carbonate system of soil solution

Table 1. Soil solution of chestnut saline solonetz, mmol-eq $\mathrm{L}^{-1}$

\begin{tabular}{|c|c|c|c|c|c|c|c|c|c|c|}
\hline $\begin{array}{l}\text { Layer, } \\
\mathrm{cm}\end{array}$ & $\begin{array}{l}\text { Moisture, } \\
\%\end{array}$ & $\begin{array}{l}\text { Solid } \\
\text { residue, } \mathrm{g} \mathrm{L}^{-1}\end{array}$ & $\mathrm{pH}$ & $\mathrm{Ca}^{2+}$ & $\mathrm{Mg}^{2+}$ & $\mathrm{Na}^{+}$ & $\mathrm{CO}_{3}^{2-}$ & $\mathrm{HCO}_{3}^{-}$ & $\mathrm{SO}_{4}^{2-}$ & $\mathrm{Cl}^{-}$ \\
\hline $0-5$ & $22,4 \pm 0,9$ & $1,64 \pm 0,39$ & $7,82 \pm 0,06$ & $4,94 \pm 0,65$ & $6,78 \pm 1,25$ & $11,22 \pm 2,02$ & absent & $4,75 \pm 1,36$ & $10,44 \pm 2,28$ & $7,75 \pm 0,95$ \\
\hline $5-14$ & $30,7 \pm 0,8$ & $6,74 \pm 1,23$ & $9,02 \pm 0,08$ & $12,33 \pm 0,98$ & $28,72 \pm 2,75$ & $60,21 \pm 7,42$ & $1,95 \pm 0,88$ & $8,64 \pm 1,99$ & $59,45 \pm 4,58$ & $31,22 \pm 2,02$ \\
\hline $14-30$ & $37,4 \pm 1,3$ & $18,10 \pm 3,82$ & $8,76 \pm 0,07$ & $23,17 \pm 1,24$ & $94,15 \pm 12,56$ & $165,73 \pm 14,65$ & $0,99 \pm 0,71$ & $8,31 \pm 1,45$ & $184,31 \pm 13,22$ & $89,44 \pm 5,24$ \\
\hline $30-40$ & $28,7 \pm 1,1$ & $35,54 \pm 3,65$ & $8,68 \pm 0,05$ & $24,84 \pm 1,78$ & $130,22 \pm 13,43$ & $400,27 \pm 21,21$ & $0,82 \pm 0,68$ & $7,74 \pm 1,82$ & $358,32 \pm 25,69$ & $188,45 \pm 13,89$ \\
\hline $70-80$ & $27,0 \pm 1,1$ & $50,58 \pm 6,21$ & $8,20 \pm 0,04$ & $35,74 \pm 3,68$ & $349,46 \pm 30,67$ & $444,42 \pm 20,33$ & absent & $6,93 \pm 1,91$ & $467,48 \pm 24,86$ & $355,21 \pm 17,34$ \\
\hline $140-150$ & $25,2 \pm 1,0$ & $38,86 \pm 4,27$ & $8,02 \pm 0,7$ & $20,41 \pm 3,79$ & $194,28 \pm 16,28$ & $414,09 \pm 30,77$ & absent & $7,15 \pm 2,38$ & $327,28 \pm 24,12$ & $294,35 \pm 18,01$ \\
\hline
\end{tabular}

To calculate the soil solution main ion's forms were used the analytical data (Table 1), Method of Ionic Pairs (MIP) (Adams, 1971): The law of initial concentration preservation, the law of the operating masses of chemical equilibrium system.

The iteration was used: To solve a system of algebraic equations of material balance of ions; linear interpolation to calculate values of tabulated equilibrium constants according calculated data. The equations of main ions material balance are as follows Equation 1-6:

$$
\sum \mathrm{Ca}^{2+}=\left[\mathrm{Ca}^{2+}\right]+\left[\mathrm{CaCO}_{3}^{\circ}\right]+\left[\mathrm{CaHCO}_{3}^{+}\right]+\left[\mathrm{CaSO}_{4}{ }^{\circ}\right]
$$

$$
\begin{aligned}
& \sum \mathrm{Mg}^{2+}=\left[\mathrm{Mg}^{2+}\right]+\left[\mathrm{MgCO}_{3}^{\circ}\right] \\
& +\left[\mathrm{MgHCO}_{3}^{+}\right]+\left[\mathrm{MgSO}_{4}^{\circ}\right] \\
& \sum \mathrm{Na}^{+}=\left[\mathrm{Na}^{+}\right]+\left[\mathrm{NaCO}_{3}^{-}\right]+\left[\mathrm{NaSO}_{4}^{-}\right] \\
& \sum \mathrm{CO}_{3}{ }^{2-}=\left[\mathrm{CO}_{3}^{2-}\right]+\left[\mathrm{CaCO}_{3}^{\circ}\right] \\
& +\left[\mathrm{MgCO}_{3}^{\circ}\right]+\left[\mathrm{NaCO}_{3}^{-}\right] \\
& \sum \mathrm{HCO}_{3}^{-}=\left[\mathrm{HCO}_{3}^{-}\right] \\
& +\left[\mathrm{CaHCO}_{3}^{+}\right]+\left[\mathrm{MgHCO}_{3}^{+}\right]
\end{aligned}
$$




$$
\begin{aligned}
& \mathrm{\Sigma SO}_{4}{ }^{2-}=\left[\mathrm{SO}_{4}{ }^{2-}\right]+\left[\mathrm{CaSO}_{4}{ }^{\circ}\right] \\
& +\left[\mathrm{MgSO}_{4}^{\circ}\right]+\left[\mathrm{NaSO}_{4}{ }^{-}\right]
\end{aligned}
$$

where, $\left[\mathrm{Ca}^{2+}\right],\left[\mathrm{Mg}^{2+}\right]$ - the equilibrium concentration of the free form of ion, $\left[\mathrm{CaCO}_{3}{ }^{0}\right],\left[\mathrm{MgCO}_{3}{ }^{0}\right]$, equilibrium concentration of associated ions.

Concentration dissociation constant of cation ionic pair follows the law of operating masses Equation 7-9:

$$
\begin{gathered}
K_{\mathrm{CaCO}_{3}}=\frac{\left[\mathrm{Ca}^{2+}\right]\left[\mathrm{CO}_{3}^{2-}\right]}{\left[\mathrm{CaCO}_{3}^{0}\right]} ; K_{\mathrm{CaHCO}_{3}}=\frac{\left[\mathrm{Ca}^{2+}\right]\left[\mathrm{HCO}_{3}^{-}\right]}{\left[\mathrm{CaHCO}_{3}^{+}\right]} \\
; K_{\mathrm{CaSO}_{4}}=\frac{\left[\mathrm{Ca}^{2+}\right]\left[\mathrm{SO}_{4}^{2-}\right]}{\left[\mathrm{CaSO}_{4}^{0}\right]} \\
K_{\mathrm{MgCO}_{3}}=\frac{\left[\mathrm{Mg}^{2+}\right]\left[\mathrm{CO}_{3}^{2-}\right]}{\left[\mathrm{MgCO}_{3}^{0}\right]} ; K_{\mathrm{MgHCO}_{3}}=\frac{\left[\mathrm{Mg}^{2+}\right]\left[\mathrm{HCO}_{3}^{2-}\right]}{\left[\mathrm{MgHCO}_{3}^{+}\right]} ; \\
K_{\mathrm{MgSO}_{4}}=\frac{\left[\mathrm{Mg}^{2+}\right]\left[\mathrm{SO}_{4}^{2-}\right]}{\left[\mathrm{MgSO}_{4}^{0}\right]} \\
K_{\mathrm{NaCO}_{3}}=\frac{\left[\mathrm{Na}^{+}\right]\left[\mathrm{CO}_{3}^{2-}\right]}{\left[\mathrm{NaCO}_{3}^{-}\right]} ; K_{\mathrm{NaSO}_{4}}=\frac{\left[\mathrm{Na}^{+}\right]\left[\mathrm{SO}_{4}^{2-}\right]}{\left[\mathrm{NaSO}_{4}^{-}\right]} .
\end{gathered}
$$

The equilibrium concentration of ionic pair was replaced in Equation 1-6 with its value according to relevant dissociation constant from Equation 7-9. The transformed system of equations of ion's material balance was obtained Equation 10-15:

$$
\begin{aligned}
& \sum \mathrm{Ca}^{2+}=\left[\mathrm{Ca}^{2+}\right]\left(1+\frac{\left[\mathrm{CO}_{3}^{2-}\right]}{K_{\mathrm{CaCO}_{3}}}+\frac{\left[\mathrm{MgCO}_{3}^{-}\right]}{K_{\mathrm{CaHCO}_{3}}}+\frac{\left[\mathrm{SO}_{4}^{2-}\right]}{K_{\mathrm{CaSO}_{4}}}\right) \\
& \sum \mathrm{Mg}^{2+}=\left[\mathrm{Mg}^{2+}\right]\left(1+\frac{\left[\mathrm{CO}_{3}^{2-}\right]}{K_{\mathrm{MgCO}_{3}}}+\frac{\left[\mathrm{HCO}_{3}^{-}\right]}{K_{\mathrm{MgHCO}_{3}}}+\frac{\left[\mathrm{SO}_{4}^{2-}\right]}{K_{\mathrm{MgSO}_{4}}}\right) \\
& \sum \mathrm{Na}^{+}=\left[\mathrm{Na}^{+}\right]\left(1+\frac{\left[\mathrm{CO}_{3}^{2-}\right]}{\mathrm{K}_{\mathrm{NaCO}_{3}}}+\frac{\left[\mathrm{SO}_{4}^{2-}\right]}{K_{\mathrm{NaSO}_{4}}}\right) \\
& \sum \mathrm{CO}_{3}^{2-}=\left[\mathrm{CO}_{3}^{2-}\right]\left(1+\frac{\left[\mathrm{Ca}^{2+}\right]}{K_{\mathrm{CaCO}_{3}}}+\frac{\left[\mathrm{Mg}^{2+}\right]}{K_{\mathrm{MgCO}}}+\frac{\left[\mathrm{Na}^{+}\right]}{K_{\mathrm{NaCO}_{3}}}\right) \\
& \sum \mathrm{CO}_{3}^{-}=\left[\mathrm{HCO}_{3}^{-}\right]\left(1+\frac{\left[\mathrm{Ca}^{2+}\right]}{\mathrm{K}_{\mathrm{CaHCO}_{3}}}+\frac{\left[\mathrm{Mg}^{2+}\right]}{\mathrm{K}_{\mathrm{MgCO}_{3}}}\right) \\
& \sum \mathrm{SO}_{4}^{2-}=\left[\mathrm{SO}_{4}^{2-}\right]\left(1+\frac{\left[\mathrm{Ca}^{2+}\right]}{K_{\mathrm{CaSO}_{4}}}+\frac{\left[\mathrm{Mg}^{2+}\right]}{K_{\mathrm{MgSO}_{4}}}+\frac{\left[\mathrm{Na}^{+}\right]}{K_{\mathrm{NaSO}_{4}}}\right)
\end{aligned}
$$

The concentration constant of dissociation was recalculated Equation 16:

$$
\mathrm{pK}=\mathrm{pK}^{0}-\mathrm{A} \Delta \mathrm{Z}^{2}\left(\frac{\sqrt{\mathrm{I}}}{1+\sqrt{\mathrm{I}}}-0,1 \mathrm{I}\right)
$$

Where:

$K=$ Concentration constant of dissociation of ionic couple

$K^{0}=$ The corresponding thermodynamic constant

$A=$ Debye-Huckel constant 0,5042 at $20^{\circ} \mathrm{C}$

$\Delta Z^{2}=$ The algebraic sum of squares of a charge of the particles in the equation of dissociation constant

$I=$ Ionic strength of solution

The calculated $\mathrm{pK}$ corresponds to (Bjerrum et al., 1958; Garrels and Christ, 1965; Debye and Hückel, 1923; Sposito, 1984).

Thermodynamic constants of dissociation from (Lurie, 1986; Handbook of chemist 21; Sposito, 1989):

$$
\begin{array}{lll}
p K_{\mathrm{CaCO}_{3}}^{0}=3,2 ; & p K_{\mathrm{CaHCO}_{3}}^{0}=1,26 ; & p K_{\mathrm{CaSO}_{4}}^{0}=2,31 . \\
p K_{\mathrm{MgCO}_{3}}^{0}=3,4 ; & p K_{\mathrm{MgHCO}_{3}}^{0}=1,16 ; & p K_{\mathrm{MgSO}_{4}}^{0}=2,36 . \\
p K_{\mathrm{NaCO}_{3}}^{0}=1,27 ; & p K_{\mathrm{NaSO}_{4}}^{0}=0,72 . &
\end{array}
$$

The formal ionic strength of soil solution according to analytical concentration Equation 17:

$$
\begin{aligned}
& \mathrm{I}=0,5\left[2^{2}\left(\mathrm{Ca}^{2+}\right)+2^{2}\left(\mathrm{Mg}^{2+}\right)+\left(\mathrm{Na}^{+}\right)\right. \\
& +2^{2}\left(\mathrm{CO}_{3}^{2-}\right)+\left(\mathrm{HCO}_{3}^{-}\right)+ \\
& \left.+2^{2}\left(\mathrm{SO}_{4}^{2-}\right)+\left(\mathrm{Cl}^{-}\right)\right], \mathrm{mol} / \mathrm{l}
\end{aligned}
$$

The equilibrium concentrations of ion's free forms were used as 6 unknowns of equation's system. Material balance according analytical concentration of chemical elements.

The equilibrium concentrations of free ions was iterated according dissociation constants (7-9).

The effective ionic force according to equilibrium concentration of all ion forms Equation 18:

$$
\begin{aligned}
& I^{*}=0,5\left\{\begin{array}{l}
2^{2}\left[\mathrm{Ca}^{2+}\right]+2^{2}\left[\mathrm{Mg}^{2+}\right]+\left[\mathrm{Na}^{+}\right] \\
+2^{2}\left[\mathrm{CO}_{3}^{2-}\right]+\left[\mathrm{HCO}_{3}^{-}\right]+2^{2}\left[\mathrm{SO}_{4}^{2-}\right]+
\end{array}\right. \\
& +\left[\mathrm{CaHCO}_{3}^{+}\right]+\left[\mathrm{MgHCO}_{3}^{+}\right]+\left[\mathrm{NaCO}_{3}^{-}\right] \\
& \left.+\left[\mathrm{NaSO}_{4}^{-}\right]+\left[\mathrm{Cl}^{-}\right)\right\}, \mathrm{mol} / \mathrm{l}
\end{aligned}
$$

At the first iteration step the concentration constants of dissociation were calculated (16). The next iteration was made on the new set of equations of material balance (10-15). 
The coefficient of ion association $\gamma_{\mathrm{e}}$ is proposed as a ratio of calculated ion free form to its analytical content Equation (19):

$$
\gamma_{\mathrm{e}}=\mathrm{C}_{\mathrm{ass}} / \mathrm{C}_{\mathrm{an}}
$$

Where:

$\mathrm{C}_{\text {ass }}=$ Calculated ion content in solution taking into account its association with another ions

$\mathrm{C}_{\mathrm{an}}=$ analytical concentration of an ion

For calculation were used the own software products (Endovitskii et al., 1985; 2009).

\section{Discussion}

The procedures specified by Equation 7-19 were used to calculate the soil solution ions association in soil horizons at the given soil moisture and analytical composition (Table 1).

The data of calculation (Table 2) represents the variation of ions association in soil layers. The real equilibrium concentration of ion forms in soil solution depends on concentration and composition of soil solution. The higher salinity of the soil solution, the more ions are associated.

On the other hand, in the non-saline horizon $0-5 \mathrm{~cm}$ of the soil at rather soil humidity the free ions forms are observed.

Because of ion association the mobility of soil solution components of dry steppe chestnut saline solonetzic is high in comparison to former analytical concentration based estimations for carbonates. It causes intensive preference solution fluxes in the soil continuum and losses of soil material to vadose zone, lateral pedosphere redistribution of salts. There is a danger of excessive carbonates loss from soil which influences the mechanical structure of soil, the calciumcarbon source for soil organisms and plants. Moreover, the migration ability of organic matter and mineral nutrients, which closely linked to soil carbonates, can be assumed significantly higher than it was previously thought because the association of ions in soil solution causes the formation of complexes of carbonates with organic and inorganic matter as a universal process for various chemicals.

In experiment, the soil solution removed from upper slightly saline soil horizon has been in diluted state. But sufficiently high soil moisture, observed in experiment, is not always common in situ. On the contrary, for the soils of southern dry regions the low soil moisture is typical. At this moisture the concentration of soil solution in the upper low saline soil horizons can be significantly higher compared to the value given in Table 1. So the soil solution material composition of upper layer of soil may be significantly influenced by association of ions in the way as it has been shown experimentally and by mathematical modeling for deep saline layers of soil. The soil system of upper soil layer is possible to describe in the model only, because now there is no way to remove the solution from dry soil.

Association of ions is fundamental base to promote innovative solutions for soil water regime correction, water saving, nutrients loss reducing, elimination of soil degradation, increase of stability and biological productivity of biosphere. It is consistent in a view of the recent data on soil moisture sensors system, corresponds to the determination of true soil solution composition (El Marazky et al., 2011). The soil moisture in artificial soil system and at the irrigation is too high from the point of view of ions association and soil solution migration (Kalinichenko, 2014a; Seitkaziev et al., 2015).

Table 2. Forms of ions in the soil solution of chestnut saline solonetz, $\%$ of the total ion content cations

\begin{tabular}{|c|c|c|c|c|c|c|c|c|c|c|c|c|}
\hline \multirow{2}{*}{$\begin{array}{l}\text { Depth, } \\
\mathrm{cm}\end{array}$} & \multicolumn{4}{|l|}{ Calcium } & \multicolumn{5}{|c|}{ Magnesium } & \multicolumn{3}{|l|}{ Sodium } \\
\hline & {$\left[\mathrm{Ca}^{2+}\right]$} & {$\left[\mathrm{CaCO}_{3}{ }^{0}\right]$} & {$\left[\mathrm{CaHCO}_{3}^{+}\right]$} & {$\left[\mathrm{CaSO}_{4}{ }^{0}\right]$} & {$\left[\mathrm{Mg}^{2+}\right]$} & {$\left[\mathrm{MgCO}_{3}{ }^{0}\right]$} & {$\left[\mathrm{MgHCO}_{3}{ }^{+}\right]$} & {$\left[\mathrm{MgSO}_{4}{ }^{0}\right]$} & {$\left[\mathrm{Na}^{+}\right]$} & {$\left[\mathrm{NaCO}_{3}{ }^{-}\right]$} & {$\left[\mathrm{NaSO}_{4}{ }^{-}\right]$} & \\
\hline $0-5$ & 78,96 & absent & 3,43 & 17,61 & 77,83 & absent & 2,69 & 19,48 & 98,91 & absent & 1,09 & \\
\hline $5-14$ & 63,14 & 2,46 & 3,17 & 31,23 & 60,36 & 3,72 & 2,41 & 33,50 & 96,28 & 0,13 & 3,59 & \\
\hline $14-30$ & 56,47 & 0,44 & 1,93 & 41,16 & 53,84 & 0,66 & 1,46 & 44,03 & 93,10 & 0,03 & 6,86 & \\
\hline $30-40$ & 48,09 & 0,24 & 1,39 & 50,29 & 45,37 & 0,35 & 1,04 & 53,23 & 89,53 & 0,02 & 10,44 & \\
\hline $70-80$ & 49,58 & absent & 1,11 & 49,31 & 46,87 & absent & 0,83 & 52,29 & 90,12 & absent & 9,88 & \\
\hline $140-150$ & 53,78 & absent & 1,36 & 44,86 & 51,13 & absent & 1,02 & 47,85 & 91,47 & absent & 8,53 & \\
\hline \multicolumn{13}{|l|}{ Anions } \\
\hline Depth, & \multicolumn{4}{|l|}{ Sulfates } & \multicolumn{3}{|c|}{ Hydrocarbons } & \multicolumn{5}{|l|}{ Carbonates } \\
\hline $\mathrm{cm}$ & {$\left[\mathrm{SO}_{4}{ }^{2-}\right]$} & {$\left[\mathrm{CaSO}_{4}{ }^{0}\right]$} & {$\left[\mathrm{MgSO}_{4}{ }^{0}\right]$} & {$\left[\mathrm{NaSO}_{4}{ }^{-}\right]$} & {$\left[\mathrm{HCO}_{3}{ }^{-}\right]$} & {$\left[\mathrm{CaHCO}_{3}{ }^{+}\right]$} & {$\left[\mathrm{MgHCO}_{3}{ }^{+}\right]$} & {$\left[\mathrm{CO}_{3}{ }^{2-}\right]$} & {$\left[\mathrm{CaCO}_{3}{ }^{0}\right]$} & {$\left[\mathrm{MgCO}_{3}{ }^{0}\right]$} & {$\left[\mathrm{NaCO}_{3}{ }^{-}\right]$} & Chlorides \\
\hline $0-5$ & 76,69 & 8,33 & 12,65 & 2,33 & 96,30 & 1,78 & 1,92 & absent & absent & absent & absent & 100 \\
\hline $5-14$ & 70,07 & 6,48 & 16,19 & 7,27 & 93,73 & 2,26 & 4,00 & 21,65 & 15,54 & 54,84 & 7,97 & 100 \\
\hline $14-30$ & 59,99 & 5,17 & 22,49 & 12,34 & 89,02 & 2,69 & 8,29 & 15,36 & 10,28 & 63,14 & 11,21 & 100 \\
\hline $30-40$ & 53,83 & 3,49 & 19,35 & 23,33 & 89,01 & 2,23 & 8,76 & 14,32 & 7,20 & 56,44 & 22,03 & 100 \\
\hline $70-80$ & 38,35 & 3,77 & 39,09 & 18,79 & 76,13 & 2,86 & 21,01 & absent & absent & absent & absent & 100 \\
\hline $140-150$ & 47,22 & 2,80 & 28,40 & 21,58 & 84,17 & 1,93 & 13,90 & absent & absent & absent & absent & 100 \\
\hline
\end{tabular}


The model proposed is applicable at $\mathrm{I}<1.0$. At this ionic strength of soil solution this model outlines the nature of the studied object on the qualitative and quantitative level. In saline soil it is possible to have the conditions of significantly greater ionic strength of the soil solution in which the need to involve other instruments to describe the structure of concentrated solution will appear (Nicholson and Quirke, 2003; Reznikov and Shaposhnik, 2005). Exotic models of this kind are very original and in special circumstances, for which they are designed, remain the exceptional way of research because are the only method to describe the process. But for all their originality, for the object of our studies those models are redundant. To describe the leading transport phenomena of matter in the soil are necessary and sufficient the thermodynamic models operating at $\mathrm{I}<1.0$.

The nature of the CCE in soils explains the origin of high calculated saturation degree of soil solutions with $\mathrm{CaCO}_{3}$ at analytical concentration of solution. Reduction of calculated supersaturation of soil solutions with $\mathrm{CaCO}_{3}$ taking into account an ionic strength is for $10 \ldots$ 50 times. A complexation of $\mathrm{Ca}^{2+}$ with soluble organic substance reduces the degree of calculated soil solution saturation with $\mathrm{CaCO}_{3}$ to 1.5 ... 2.0 times.

The ion association can explain the excess of analytical concentration of ions in soil solution over the ion thermodynamic solubility product.

\section{Conclusion}

The association and activity of ions, calculation of soil solution saturation degree provides new knowledge of migration and accumulation of salts and $\mathrm{CaCO}_{3}$ in soils and landscapes.

Thus, the study of most important chemical equilibria and ionic structure of soil solution help to determine the formation and nature of chemical composition of saline soil. The approach proposed permits to consider the processes of migration and accumulation of salts, to predict the genesis, evolution and different methods of reclamation of soil and landscape systems.

The association of ions is a thermodynamic precondition of $\mathrm{CaCO}_{3}$ oversaturation and sedimentation in saline soils at higher concentration of $\mathrm{Ca}^{2+}$ and $\mathrm{CO}_{3}{ }^{2-}$ in soil solution than it was considered before. At high ionic force in soil solution are formed electrically neutral ion pairs $\mathrm{CaCO}_{3}{ }^{0} ; \mathrm{CaSO}_{4}{ }^{0}, \mathrm{MgCO}_{3}{ }^{0}, \mathrm{MgSO}_{4}{ }^{0}$, charged ion pairs $\mathrm{CaHCO}_{3}^{+}, \mathrm{MgHCO}_{3}^{+}, \mathrm{NaCO}_{3}^{-}, \mathrm{NaSO}_{4}^{-}$, $\mathrm{CaOH}^{+}, \mathrm{MgOH}^{+}$. It causes a high mobility of $\mathrm{CaCO}_{3}$ in soil continuum and landscape.

Our scheme of soil solution system modeling is of high scientific and practical prospect even compared to up-to-date direct methods of soil solution research. The system luck of soil solution probing is the new state of solution after its extraction from soil, an artificial system does not reflect the real soil solution.

The idea of ions association in the soil solution is a method to model quantitatively the equilibria processes in soil solution, soil and landscape. The research fulfilled on example of dry steppe chestnut saline solonetzic soil of Southern Russia shows dangerous for biosphere uncertainty of terrestrial carbon sink from soil. To the great extend it is linked to high mobility of carbon in the soil solution in form of carbonates. Concerning preferable water flows (Kalinichenko et al., 1997; Shein et al., 2014; Shein, 2015; Shein et al., 2015), the soil geochemical barriers for carbonates are less stable as it was previously thought. Thus the association of ions in soil solutions is a driver of carbon loss from soil to other geospheres (Kalinichenko et al., 2012; Kalinichenko, 2014b; Kalinichenko and Starcev, 2015). An excess of carbon sink from biosphere through the soil is of high probability. Correction of phases and stages of carbon in soil for stabilizing of climate is a challenging task (Glazko and Glazko, 2015; Kalinitchenko et al., 2014a; 2014b; Kalinichenko, 2015a; 2015b; Sobgayda and Solodkova, 2015; Yuan et al., 2014).

\section{Acknowledgement}

The author thanks Chechen State University, Institute of Fertility of Soils of South Russia, Southern Federal University for supporting this research.

\section{Funding Information}

The reported study was funded by the Russian Science Foundation (no. 16-14-10217).

\section{Author's Contributions}

Abdulmalik A. Batukaev: Designed the research plan and organized the study, coordinated the data analysis.

Anatoliy P. Endovitsky: Head of investigation is proposed the idea of ion's association in soil solution, suggested system of equations.

Andrey G. Andreev: Developed the mathematical model.

Tatiana M. Minkina: Participated in all experiments and coordinated the data-analysis.

Valeriy P. Kalinichenko: Interpreted the model and prepared the manuscript with contributions and wishes of all co-authors.

Marina V. Burachevskaya, Zaurbek S. Dikaev and Saglara S. Mandzhieva: Carried out the experiment.

Svetlana N. Sushkova: Collected the field data, performed the statistical analysis. 


\section{Ethics}

The authors have no conflicts of interest in the development and publication of current research.

\section{References}

Adams, F., 1971. Ionic concentrations and activities in soil solutions. Soil Sci. Soc. Am. J., 35: 421-426. DOI: 10.2136/sssaj1971.03615995003500030028x

Ågren, A.M., I. Buffam, D.M. Cooper, T. Tiwari and C.D. Evans et al., 2014. Can the heterogeneity in stream dissolved organic carbon be explained by contributing landscape elements? Biogeosciences, 11: 1199-1213. DOI: $10.5194 /$ bg-11-1199-2014

Amakor, X.N., A.R. Jacobson and G.E. Cardon, 2013. Improving estimates of soil salinity from saturation paste extracts in calcareous soils. Soil Sci. Soc. Am. J., 3: 792-799. DOI: 10.2136/sssaj2012.0235, 2013

Anisimov, V.S., L.N. Anisimova, L.M. Frigidova, D.V. Dikarev and RA. Frigidov et al., 2015. Evaluation of migration ability of $\mathrm{Zn}$ in the soilplant system. Biogeosyst. Technique, 4: 153-163. DOI: $10.13187 /$ bgt.2015.4.153

Bahn, M., M. Reichstein, K. Guan, J. Moreno and C. Williams, 2015. Climate extremes and biogeochemical cycles in the terrestrial biosphere: Impacts and feedbacks across scales. Biogeosciences, 12: 4827-4830. DOI: $10.5194 /$ bg-12-4827-2015

Besser-Rogac, M., A. Stoppa, J. Hunger, G. Hefter and R. Buchner, 2011. Association of ionic liquids in solution: A combined dielectric and conductivity study of $[\mathrm{bmim}][\mathrm{Cl}]$ in water and in acetonitrile. Phys. Chem. Chem. Phys., 13: 17588-1759.

DOI: $10.1039 / \mathrm{C} 1 \mathrm{CP} 21371 \mathrm{G}$

Bjerrum, J., G. Schwarzenbach and L. Sillen, 1958. Stability Constants of Metal-ion Complexes, with Solubility Products of Inorganic Substances: Inorganic Ligands. Chemical Society, London, 1st Edn., pp: 236.

Butler, J.N., 1998. Ionic Equilibrium. 1st Edn., John Wiley and Sons, Inc., New York, ISBN-10: 0471585262, pp: 559.

Carter, M.R. and E.G. Gregorich, 2007. Soil Sampling and Methods of Analysis. 2nd Edn., CRC Press, ISBN-10: 1420005278, pp: 1264.

Chaplygin, V.A., T.M. Minkina, S.S. Mandzhieva, S.N. Sushkova and O.G. Nazarenko et al., 2014. Steppe zone vegetation and soil layer pollution by heavy metals under the influence Novocherkassk power station emission. Biogeosyst. Technique, 1: 50-57. DOI: 10.13187/bgt.2014.1.50

Chialvo, A.A., P.T. Cummings, H.D. Cochran, J.M. Simonson and R.E. Mesmer, 1995. $\mathrm{Na}^{+}-\mathrm{Cl}^{-}$ion pair association in supercritical water. J. Chem. Phys., 103: 9125-9516.
Davies, C.W., 1962. Ion Association. 1st Edn., Butterworths, London, pp: 190.

Debye, P. and E. Hückel, 1923. The theory of electrolytes. I. Lowering of freezing point and related phenomena. Physikalische Zeitschrift, 24: 185-206.

El Marazky, M.S.A., F.S. Mohammad and H.M. Al-Ghobari, 2011. Evaluation of soil moisture sensors under intelligent irrigation systems for economical crops in arid regions. Am. J. Agri. Biol. Sci., 6: 287-300.

DOI: 10.3844/ajabssp.2011.287.300

Endovitskii, A.P. and M.B. Minkin, 1979. New method of calculation the equilibrium ionic composition of soil solutions. Soil Sci., 5: 103-108.

Endovitskii, A.P., A.A. Gavrilov and M.B. Minkin, 1985. Calculation of natural waters saturation by calcium carbonate taking into account association of ions and its influence on proton balance of carbonate system (PROTON). The Annotated list of new receipts of OFAP Goskomgidrometa. Obninsk, 3: 11-11.

Endovitskii, A.P., V.P. Kalinichenko, T.M. Minkina, S.S. Mandzhieva and S.N. Sushkova, 2014. Lead status in chernozem of the Krasnodar krai after the application of phosphogypsum. Middle-East J. Scientific Res., 22: 954-959.

DOI: 10.5829/idosi.mejsr.2014.22.07.21980

Endovitskii, A.P., V.P. Kalinichenko, S.Y. Bakoyev, A.A. Ivanenko and V.A. Sukovatov et al., 2009. Certificate of the state registration of computer program No 2009612162 «ION-2". Don State Agrarian University, Patentee.

Endovitsky, A.P., V.P. Kalinichenko and T.M. Minkina, 2014a. State of lead and cadmium in chernozem after making phosphogypsum. Soil Sc., 3: 340-350. DOI: $10.7868 / \mathrm{S} 0032180 \mathrm{X} 14030058$

Endovitsky, A.P., T.M. Minkina, V.P. Kalinichenko, A.A. Batukaev and Z.S. Dikaev et al., 2014b. The association of ions in the soil solution of saline soils. Am. J. Agric. Biol. Sci., 9: 238-244. DOI: 10.3844 /ajabssp.2014.238.244

Endovitsky, A.P., V.P. Kalinichenko and T.M. Minkina, 2015a. carbonate calcium equilibrium in soil solution as a driver of heavy metals mobility. Int. J. Environ. Problems, 2: 136-153. DOI: 10.13187/ijep.2015.2.136

Endovitsky, A.P., T.M. Minkina and V.P. Kalinitchenko, 2015b. Thermodynamic status of strontium in chernozem at application of phosphogypsum. Biogeosyst. Technique, 6: 345-362. DOI: $10.13187 /$ bgt.2015.6.345

Evans, W., J.T. Mathis and J.N. Cross, 2014. Calcium carbonate corrosivity in an Alaskan inland sea. Biogeosciences, 11: 365-379. DOI: $10.5194 /$ bg-11-365-2014 
Farnum, B.H., J.M. Gardner, A. Marton, A.A. Narducci-Sarjeant and G.J. Meyer, 2011. Influence of ion pairing on the oxidation of iodide by MLCT excited states. Dalton Trans., 40: 3830-3838. DOI: 10.1039/C0DT01447H

Garrels, R.M. and C.L. Christ, 1965. Solutions, Minerals and Equilibria. 2nd Edn., Harper and Row, New York, pp: 450.

Glazko, V.I. and T.T. Glazko, 2015. Conflicts of biosphere and agroecosystems. Int. J. Environ. Problems, 1: 4-16. DOI: 10.13187/ijep.2015.1.4

Handbook of chemist 21. http://chem21.info/info/715782/

Hunenberger, P. and M. Relf, 2011. Single-Ion Salvation. In: Experimental and Theoretical Approachs to Elusive Thermodynamic Quantities. Hirst, J. (Ed.), Royal Society of Chemistry, Thomas Graham House, Science Park, Milton Road, UK. Cambrige, ISBN-13: 978-1-84755-187-0, pp: 690.

Izgorodina, E.I., D. Golze, R. Maganti, V. Armel and M. Taige et al., 2014. Importance of dispersion forces for prediction of thermodynamic and transport properties of some common ionic liquids. Phys. Chem. Chem. Phys., 16: 7209-7221.

DOI: $10.1039 / \mathrm{C} 3 \mathrm{CP} 53035 \mathrm{C}$

Jiang, C.L., J.M. Sequaris, H. Vereecken and E. Klumpp, 2012. Effects of inorganic and organic anions on the stability of illite and quartz soil colloids in $\mathrm{Na}^{-}, \mathrm{Ca}-$ and mixed $\mathrm{Na}-\mathrm{Ca}$ systems, colloids and surfaces $\mathrm{A}$ : Physicochem. Eng. Aspects, 415: 134-141. DOI: 10.1016/j.colsurfa.2012.10.007

Johnston, J.C., N. Kastelowitz and V. Molinero, 2010. Liquid toquasicrystaltransition in bilayerwater. J. Chem. Phys., 133: 154516. PMID: 20969412

Kalinichenko, V.P., 2014a. Biogeosystem technique as a problem. Biogeosyst. Technique, 1: 4-19. DOI: 10.13187/bgt.2014.1.4

Kalinichenko, V.P., 2014b. Biogeosystem technique as a base of the new world water strategy. Biogeosyst. Technique, 2: 100-124.

DOI: $10.13187 /$ bgt.2014.2.100, 2014

Kalinichenko, V.P., 2015a. Biogeosystem technique as a paradigm of non-waste technology in the biosphere, Biogeosyst. Technique, 3: 4-28.

DOI: $10.13187 /$ bgt.2015.3.4

Kalinichenko, V.P., 2015b. Biogeosystem technique as the method for earth's climate stabilizing. Biogeosyst. Technique, 4: 104-137.

DOI: $10.13187 /$ bgt.2015.4.104

Kalinitchenko, V.P., A.A. Batukaev, A.A. Zarmaev, T.M. Minkina and V.F. Starcev et al., 2014a. Biogeosystem technique as a contribution to global food sustainability. Proceedings of the 248th ACS National Meeting and Exposition, Aug. 10-14. AGRO, San Francisco, pp: 143: 37.
Kalinitchenko, V.P., A.A. Batukaev, V.E. Zinchenko, A.A. Zarmaev and A.S. Magomadov et al., 2014 b. Biogeosystem technique as a method to overcome the biological and environmental hazards of modern agricultural, irrigational and technological activities. Geophys. Res. Abs., 16: 17015-17015.

Kalinichenko, V.P., M.M. Kodzoev, A.M. Tochiev, B.B. Mamilov and M.A. Bazgiev, 2012. Soil ecosystem management in birdlime utilization. Eur. Res., 25: 1042-1049.

Kalinichenko, V.P., O.G. Nazarenko and L.P. Ilina, 1997. Features of the structural organization of the soil mass in waterlogged soil slopes chernozem zone. Rep. Russ. Acad. Agric. Sci., 5: 22-24.

Kalinichenko, V.P. and V.F. Starcev, 2015. Recycling of poultry litter by method of biogeosystem technique. Int. J. Environ. Problems, 1: 17-48.

DOI: $10.13187 /$ ijep.2015.1.17

Kielpinski, D., 2013. Viewpoint: Ion pair simulates hybrid excitations. Physics, 6: 112-112. DOI: 10.1103/Physics.6.112

Leiber-Sauheitl, K., R. Fuß, C. Voigt and A. Freibauer, 2014. High $\mathrm{CO}_{2}$ fluxes from grassland on histic Gleysol along soil carbon and drainage gradients. Biogeosciences, 11: 749-761.

DOI: $10.5194 /$ bg-11-749-2014

Levchenko, V.M., 1921. Theoretical Foundations of physical and chemical research of natural waters. Hydro-Chemical Mater., 35: 75-75.

Lewis, G.N. and M. Randell, 2015. The Activity coefficients of strong electrolytes. Am. Chem. Society J., 43: 1112-1154.

Lima, I.D., P.J. Lam and S.C., Doney, 2013. Dynamics of particulate organic carbon flux in a global ocean model. Biogeosciences, 11: 1177-1198. DOI: $10.5194 /$ bg-11-1177-2014

Lui, M.Y., L. Crowhurst, J.P. Hallett, P.A. Hunt and H. Niedermeyer et al., 2011. Salts dissolved in salts: Ionic liquid mixtures. Chem. Sci., 2: 1491-1496. DOI: $10.1039 / \mathrm{C} 1 \mathrm{SC} 00227 \mathrm{~A}$

Luo, Y., W. Jiang, H. Yu, A.D. MacKerell and B. Roux, 2013. Simulation study of ion pairing in concentrated aqueous salt solutions with a polarizable force field. Faraday Discuss, 160: 135-149. DOI: $10.1039 / \mathrm{C} 2 \mathrm{FD} 20068 \mathrm{~F}$

Lurie, Y.Y., 1986. Handbook of Analytical Chemistry. 1st Edn., Chemistry, Moscow.

Maiti, A. and R.D. Rogers, 2011. A correlation-based predictor for pair-association in ionic liquids. Phys. Chem. Chem. Phys., 13: 12138-12145. DOI: $10.1039 / \mathrm{C} 1 \mathrm{CP} 21018 \mathrm{~A}$

Melton, J. R. and V.K. Arora, 2014. Sub-grid scale representation of vegetation in global land surface schemes: Implications for estimation of the terrestrial carbon sink. Biogeosciences, 11: 1021-1036.

DOI: $10.5194 /$ bg-11-1021-2014 
Mezbahuddin, M., R.F. Grant and T. Hirano, 2014. Modeling effects of seasonal variation in water table depth on net ecosystem $\mathrm{CO}_{2}$ exchange of a tropical peatland. Biogeosciences, 11: 577-599.

DOI: $10.5194 /$ bg-11-577-2014

Minkin, M.B. and A.P. Endovitsky, 1986. Conditions for the formation of the chemical composition of soil solutions, Proceedings of the XIII Congress of the International Society of Soil Science. Hamburg, 11: 396-397.

Minkin, M.B, A.P. Endovitsky and V.M. Levchenko, 1977. Association of ions in the soil solution. Soil Sci., 2: 49-58.

Minkina, T.M., A.P. Endovitsky, V.P. Kalinichenko and Y.A. Fedorov, 2012. Calcium carbonate equilibrium in the system water-soil. Southern Federal University, Rostov-on-Don.

Minkina, T.M., G.V. Motusova, S.S. Mandzhieva and O.G. Nazarenko, 2012. Ecological resistance of the soil-plant system to contamination by heavy metals. J. Geochem. Explorat., 123: 33-40.

DOI: $10.1016 /$ j.gexplo.2012.08.021

Müller, M.N., M. Lebrato, U. Riebesell, J. Barcelos e Ramos and K.G. Schulz et al., 2014. Influence of temperature and $\mathrm{CO}_{2}$ on the strontium and magnesium composition of coccolithophore calcite. Biogeosciences, 11: 1065-1075.

DOI: $10.5194 /$ bg-11-1065-2014

Nauer, P.A., E. Chiri, J. Zeyer and M.H. Schroth, 2013. Technical note: Disturbance of soil structure can lead to release of entrapped methane in glacier forefield soils. Biogeosciences, 11: 613-620. DOI: $10.5194 / \mathrm{bg}-11-613-2014$

Nicholson, D. and N. Quirke, 2003. Ion pairing in confined electrolytes. Molecular Simulat., 29: 287-290. DOI: 10.1080/0892702031000078427

Orlov, D.S., 1992. Soil Chemistry. 1st Edn., Oxford and IBH Publishing Co. Pvt. Ltd, pp: 390.

Peng, Y., V.K. Arora, W.A. Kurz, R.A. Hember and B.J. Hawkins et al., 2014. Climate and atmospheric drivers of historical terrestrial carbon uptake in the province of British Columbia, Canada. Biogeosciences, 11: 635-649.

DOI: $10.5194 /$ bg-11-635-2014

Plugatyr, A., R.A. Carvajal-Ortiz and I.M. Svishchev, 2011. Ion-pair association constant for $\mathrm{LiOH}$ in supercritical water. J. Chem. Eng. Data, 56: 3637-3642. DOI: $10.1021 /$ je2004808

Raiteri, P., R. Demichelis, J.D. Gale, M. Kellermeier and D. Gebauer et al., 2012. Exploring the influence of organic species on pre- and post-nucleation calcium carbonate. Faraday Dis., 159: 61-85.

DOI: $10.1039 / C 2 F D 20052 J$
Reichstein, M., M. Bahn, P. Ciais, D. Frank and M.D. Mahecha et al., 2013. Climate extremes and the carbon cycle. Nature, 500: 287-295.

Reznikov, A.A. and V.A. Shaposhnik, 2005. Computer simulation of the formation of ion pairs in the electrolyte solution. Bull. Voronez State Univ., 2: 65-68.

Romanou, A., J. Romanski and W. Gregg, 2013. Natural ocean carbon cycle sensitivity to parameterizations of the recycling in a climate model. Biogeosciences, 11: 1137-1154. DOI: 10.5194/bg-11-1137-2014

Saito, C.H., 2013. Environmental education and biodiversity concern: Beyond the ecological literacy. Am. J. Agric. Biol. Sci., 8: 12-27.

DOI: 10.3844/ajabssp.2013.12.27

Seitkaziev, A.S., A.U. Taichibekov, L.B. Kashkynbaeva, G.A. Sholpankulova and Z.S. Dyusenbaeva et al., 2015. Environmental assessment and improvement of saline lands in irrigated agriculture. Int. J. Environ. $\quad$ Prob., 1: 59-63. DOI: $10.13187 /$ ijep.2015.1.59

Seneviratne, S.I., N. Nicholls, D. Easterling, C.M. Goodess and S. Kanae et al., 2012. Changes in Climate Extremes and their Impacts on the Natural Physical Environment. In: Managing the Risks of Extreme Events and Disasters to Advance Climate Change Adaptation, Field, C.B., V. Barros, T.F. Stocker, D. Qin and D.J. Dokken et al. (Eds.), IPCC SREX Report, pp: 109-230.

Shein, E.V., 2015. Mathematical physically based models in soil science: History of development, current status, problems and perspectives (Analytical Review). Soil Sci., 7: 816-816. DOI: 10.7868/S0032180X15070096

Shein, E.V., S.A. Erol, E.Y. Milanovskiy, F.D. Mikailsoy and N.V. Verhovtseva, 2015. Soil processes in haplic kastanozems of central Anatolia (Turkey, Ćumra Region): Bio- and agrophysical aspects. Biogeosyst. Technique, 4: 185-188. DOI: $10.13187 /$ bgt.2015.4.185

Shein, E.V., N.S. Kukharuk and S.S. Panina, 2014. Soil water retention curve: Experimental and pedotransfer data to forecast water movement in soils. Biogeosyst. Technique, 1: 89-96. DOI: $10.13187 /$ bgt.2014.1.89

Sobgayda, N.A. and A.B. Solodkova, 2015. Recycling spent activated sludge. Int. J. Environ. Problems, 1: 64-74. DOI: 10.13187/ijep.2015.1.64

Sposito, G., 1984. The future of an illusion: Ion activities in soil solutions. Soil Sci. Society Am. J., 48: 531-536.

Sposito, G., 1989. The Chemistry of Soils. 1st Edn., Oxford University Press, New York, ISBN-10: 0195046153, pp: 277. 
Starcev Viktor, F. and V.P. Kalinichenko, 2015. Utilization of biological waste by biogeosystem technics method. Int. J. Environ. Problems, 2: 166-182. DOI: 10.13187/ijep.2015.2.166

Stoyanov, E.S., I.V. Stoyanova and C.A. Reed, 2011. The unique nature of $\mathrm{H}^{+}$in water. Chem. Sci., 2: 462-472. DOI: 10.1039/C0SC00415D

Teichert, S. and A. Freiwald, 2014. Polar coralline algal $\mathrm{CaCO}_{3}$-production rates correspond to intensity and duration of the solar radiation. Biogeosciences, 11: 833-842. DOI: $10.5194 /$ bg-11-833-2014

Tertre, E., D. Pret and E. Ferrage, 2011. Influence of the ionic strength and solid/solution ratio on $\mathrm{Ca}$ (II)-for$\mathrm{Na}+$ exchange on montmorillonite. Part 1: Chemical measurements, thermodynamic modeling and potential implications for trace elements geochemistry. J. Colloid Interface Sci., 353: 248-256. DOI: $10.1016 /$ j.jcis.2010.09.039

Turi, G., Z. Lachkar and N. Gruber, 2014. Spatiotemporal variability and drivers of $\mathrm{CO}_{2}$ and air-sea $\mathrm{CO}_{2}$ fluxes in the california current system: An eddy-resolving modeling study. Biogeosciences, 11: 671-690. DOI: 10.5194/bg-11-671-2014

Visconti, F. and J.M. de Paz, 2012. Prediction of the soil saturated paste extract salinity from extractable ions, cation exchange capacity and anion exclusion. Soil Res., 50: 536-550. DOI: 10.1071/SR12197
Wang, T., J. Liu, H. Sun, L. Chen and J. Dong et al., 2014. Exploring the mechanism of ion-pair recognition by new calix[4]pyrrole bis-phosphonate receptors: Insights from quantum mechanics study. RSC Adv., 4: 1864-1873.

DOI: $10.1039 / \mathrm{C} 3 \mathrm{RA} 44380 \mathrm{~A}$

Westerlund, F., J. Elm, J. Lykkebo, N. Carlsson and E. Thyrhaug et al., 2011. Direct probing of ion pair formation using a symmetric triangulenium dye. Photochem. Photobiol. Sci., 10: 1963-1973. DOI: $10.1039 / \mathrm{C} 1 \mathrm{PP} 05253 \mathrm{E}$

Wiatrak, P., 2014. Evaluation of nitrogen application methods and rates with nutrisphere-n on soil nitratenitrogen in southeastern coastal plains. Am. J. Agric. Biol. Sci., 9: 64-71. DOI: 10.3844 /ajabssp.2014.64.71

Yuan, X., E.F. Wood and M. Liang, 2014. Integrating weather and climate prediction: Towards seamless hydrologic forecasting. Geophys. Res. Lett., 41: 5891-5896. DOI: 10.1002/2014GL061076

Zhang, L., J.E. Petersen, W. Zhang, Y. Chen and M. Cabrera et al., 2012. Interactions of 14C-labeled multi-walled carbon nanotubes with soil minerals in water. Environ. Pollut., 166: 75-81.

DOI: $10.1016 /$ j.envpol.2012.03.008 